\title{
Zarys pojęcia świętości w życiu człowieka - patroni i orędownicy od chorób wszelakich
}

\author{
Wiktor Orlof \\ Uniwersytecki Szpital Kliniczny w Białymstoku (UMB), \\ Chrześcijańska Akademia Teologiczna w Warszawie (ChAT), \\ Polska \\ ORCID: 0000-0002-5147-7269 \\ w_orlof@wp.pl
}

\section{Maria Antonowicz}

Muzeum Historyczne w Sanoku, Polska ORCID: 0000-0001-9898-026X

maria_antonowicz@o2.pl

W. Orlof, M. Antonowicz, An outline of the concept of the sanctity of human life-patrons and advocates of all sorts of diseases, Elpis, 22 2020: 127-133.

\begin{abstract}
The creator of the cosmos and the human race has made the world perfect and lasting in perfect harmony. God made man in paradise to live forever and then remain healthy in any sphere. Deficiencies, martyrdom, melancholy, suffering appeared at the time of the fall of man and falling into sin ( $\sin$ of the forefathers). All religious practices are a bridge between the empirical world of matter and the transcendent spiritual world. In order to achieve full health, the coexistence of the spiritual and bodily sphere, and their coexistence, is extremely important.

Man converts ontologically, turning away from the opposite pathological condition and returns to God, regaining the health of his nature. Initially, the spiritual heals, that is, the soul, then the psyche and somatics. Among the many saints, doctors have their patrons, while their patients - many advocates in all sorts of diseases. Everyday many patients and doctors ask saints for support during the fight against diseases. The lives of many saints and often their martyrdom and death can be an example of living and resisting problems. The text presents a list of nearly a hundred holy advocates in many diseases. Everyone pleads before Christ and presents our prayers and pleas to God. Prayer, especially with a request for the intercession of saints, can be extremely helpful when trying to restore health.
\end{abstract}

\begin{abstract}
Streszczenie: Stwórca kosmosu oraz rodzaju ludzkiego uczynił świat doskonałym i trwającym w idealnej harmonii. Bóg uczynił człowieka w Raju, aby żył wiecznie, pozostawał wówczas zdrowy w każdej sferze. Niedomagania, martyrologia, melancholia, cierpienie pojawiły się w chwili upadku człowieka i popadnięciu w grzech (grzech praojców). Wszelkie praktyki religijne stanowią pomost pomiędzy empirycznym światem materii oraz transcendentnym światem duchowym. Chcąc osiągnąć pełnię zdrowia, niezwykle ważne jest współistnienie sfery duchowej, cielesnej, ich koegzystencja.

Człowiek nawraca się ontologicznie, odwracając się od przeciwnego naturze patologicznego stanu i powraca do Boga, odzyskując zdrowie swej natury. Początkowo uzdrawia się to, co duchowe, czyli to, co związane z dusza, nastepnie psychika i somatyka. Wśród grona licznych świętych lekarze posiadają swoich patronów, zaś ich podopieczni - pacjenci wielu orędowników w chorobach wszelakich. Wielu pacjentów, jak i lekarzy codziennie zanosi prośby o wsparcie podczas walki z chorobami. Życie wielu świętych i niejednokrotnie ich męczeństwo i śmierć mogą być przykładem życia i stawiania oporu problemom. W tekście przedstawiono listę niespełna setki świętych orędowników w wielu chorobach. Wszyscy orędują przed obliczem Chrystusa i przedstawiają Bogu nasze prośby i błagania. Modlitwa szczególnie z prośbą o wstawiennictwo świętych może być wyjątkowo pomocna przy próbie przywrócenia zdrowia.
\end{abstract}

Keywords: religion, prayer, health, saints

Słowa kluczowe: religia, modlitwa, zdrowie, święci

\section{Wstęp}

Stwórca kosmosu i dalej rodzaju ludzkiego uczynił materię ożywioną i nieożywioną, doskonałą i trwającą ze sobą w idealnej harmonii. Anthropos ${ }^{1}$, słowo zaczerpnięte z Biblii określające gatunek ludzki, odnosi się do stworzenia człowieka jako całości na Boży obraz i podobieństwo (Rdz 1,26-27), a więc mówi o istocie pozbawionej braków. Bóg ,ulepił” człowieka niczym doskonały garncarz i powiedział, że było to bardzo dobre (Księga rodzaju 1,27.31

\footnotetext{
Anthropos - mówi o człowieku (jak o gatunku), który staje się nowy w kategorii jakości, choć nigdy wcześniej nie istniał.
}

- „I stworzyt Bóg czlowieka na obraz swój. Na obraz Boga stworzyt go. Jako mężczyznę $i$ niewiaste stworzyt ich. I spojrzat Bóg na wszystko, co uczynit, a byto to bardzo dobre.") (Biblia Jerozolimska, 2006). W obliczu tajemnicy i ograniczeń poznawczych stworzenia-człowieka, niemożliwe do objęcia światowej masie słowa o Bożej kreacji z Księgi Rodzaju, wybrzmiewają. Ów cudowny głos - Logos - szepcze władczo, iż całość stworzenia nie jest panem swego bytu, ale ów mistyczny byt jest mu dany. Zatem w sercu stworzenia rozlega się niepohamowany i nie milknący półgłos mówiący, że korzeń twojego bytu nie znajduje się w tobie, ale jesteś stworzonym! Ten głos, choć brzmi wyraźnie, może zostać odrzucony, gdyż wia- 
ra jest wolna, bo byt jest wolny i nie zna przymusowości (Bułgakow, 2011, s. 260). Niegdyś martwi „Adamici”, dziś zostaliśmy ożywieni w Chrystusie (1 Kor 15,22) (Watson, 2017, s. 46). Człowiek, choć istota skończona, pomimo tego stanowi odbicie Boskich cech takich jak: prawda, osobowość, mądrość, miłość, sprawiedliwości i świętość (Watson, 2017a, s. 15).

Bóg stworzył „praczłowieka”, ażeby wiecznie żył. W tamtym okresie nie istniały na ziemi grzech, ból, cierpienie, a także choroby, których konsekwencją jest śmierć. Człowiek pozostawał w pełni zdrowy w każdej sferze. Niedomagania, martyrologia, melancholia, cierpienie pojawił się w chwili upadku człowieka i popadnięciu w grzech (grzech praojców).

Każda choroba, zarówno ciała, jak i duszy, jest rezultatem upadku i występku człowieka. Proste i bezpośrednie obcowanie z Bogiem, które było udziałem praojców w Raju, zostało brutalnie przerwane. Bóg „oddalił się”2 od świata i człowieka, aby stać się transcendentnym ${ }^{3}$. Mocne poczucie/świadomość oddalenia bytu stworzonego od Stwórcy obudził w człowieku sam szatan, by wywołać bunt stworzenia przeciw własnej podstawie -Stwórcy. Religia i wszelkie praktyki religijne są objawem wysiłku, jaki podejmuje człowiek, aby przedrzeć się przez powstałą „,ciemność” do światłości poznania Boga - Stwórcy: „a światłość w ciemności świeci i ciemność jej nie ogarnęła" (J.1, 5). W Raju, jak pisze (Bułgakow, 2011, s. 445), człowiek nie czuł dystansu między Bogiem a sobą, dlatego nie czuł pragnienia jednoczenia się z Nim. „Eli, Eli, lema sabachthani - Boże mój, Boże mój, czemuś mnie opuścił" (Mk 15,34$)^{4}$ to najwyższy wyraz poczucia rozłąki i wołania o zjednoczenie.

Zatem wszelkie praktyki religijne stanowią pomost pomiędzy empirycznym światem materii oraz transcendentnym światem duchowym. Chcąc osiągnąć pełnię zdrowia, niezwykle ważne jest wspótistnienie sfery duchowej oraz sfery cielesnej, ich koegzystencja (Chuengsatiansup, 2003). Modlitwa, szczególnie z prośbą o wstawiennictwo świętych, może być wyjątkowo pomocna.

\section{Cel i struktura pracy}

Celem niniejszego artykułu jest przegląd literatury zarówno teologicznej, hagiograficznej, jak i medycznej w celu przedstawienia współczesnego spojrzenia na problem przenikania się kwestii zdrowia człowieka oraz dróg do pełni jego osiągnięcia. Ważnym punktem tego artykułu stanowi podrozdział dotyczący świętych patronów od chorób wszelakich. Chory szukający pomocy, znajdzie w niniejszym rozdziale patrona i orędownika, przez którego

\footnotetext{
Chociaż tak naprawdę człowiek oddalił się od Boga poprzez nieposłuszeństwo (Rdz 3)

3 Transcendentny - to inaczej wymykający się zwykłemu ludzkiemu doświadczeniu, wykraczający poza zasięg ludzkiego poznania przy pomocy podstawowych pięciu zmysłów; niepoznawalny przy użyciu dostępnych środków naukowych.

4 Mk 15, 34 - Ps 22[21],2 nieco inne brzmienie niż Mt 27,46.
}

wstawiennictwo może liczyć na pomoc i ukojenie. Dalej artykuł ten stanowi ciągłość i uzupełnienie wcześniejszego tekstu pt.:"Nieeteryczny zwiazek między duchowościa Chrześcijańska a zdrowiem człowieka"s.

\section{Duchowe przyczyny choroby i droga do zdrowia}

Wszelkie złamanie moralnych norm, każdy upadek i grzech co do zasady może sprowokować chorobę ciała i duszy.

W Biblii spotykamy greckie słowo paraptoma - co oznacza wszelki występek. Symbolizuje ono odchylenie się i zejście z prawej drogi. Słowo to w Nowym Testamencie pojawia się w miejscach mówiących o zamierzonym działaniu, które pociąga za sobą poważne konsekwencje odstępstwa od Bożych zasad. Konsekwencją tego występku jest grzech. Grzech z gr. hamartia - nie trafić w cel, chybić, określenie to stawia nas twarzą w twarz z tym, co kryje się pod pojęciem grzechu, otóż z chybieniem celu, wobec tego $\mathrm{z}$ faktem, że nie jesteśmy tym, kim powinniśmy być i tym, kim moglibyśmy być (Barclay, 1982). Grzeszymy dlatego, że wybieramy grzech, czynimy w ten sposób odstępstwo od Bożej woli. Z grzechem tracimy łączność z Logosem. Prawa moralne pochodzące z dziesięciu przykazań są co rusz łamane w społeczeństwie (co wydaje się nasilać z roku na rok?), dlatego ludzie chorują z powodu własnego nieprzyzwoitego i niegodziwego życia. Choroba najpierw ducha i psychiki po latach obecności zaczyna objawiać się pod postacią niedomagań somatycznych.

Praktyki religijne tworzą niewidzialną rampę między empirycznym światem materii a transcendentnym światem duchowym, są niezbędne w przywróceniu jedności z Absolutem. Wielu teologów i egzegetów chrześcijańskich, w tym także (Hume, 1983, s. 36-40) w książce pt. „W poszukiwaniu Boga" pisało, że praktyki religijne powinny stać się tym samym dla rozwoju sfery duchowej, czym stały się ćwiczenia fizyczne dla stanu fizycznego, celem osiągnięcia pełni zdrowia (Śliwerski, 2007, s. 15-34).

Zagadnienia dotyczące zdrowia człowieka, jak wykazano powyżej, nierozerwalnie funkcjonują i związane są silnie ze stanem natury ludzkiej, jaką to naturę otrzymał nasz praojciec - Adam. W Biblijnym ojcu i matce ludzkości występowała idealna harmonia wolnej woli stworzenia z obecnością Bożej łaski Stwórcy. Z owej koegzystencji wynika sens, który jest widoczny w jej ukierunkowaniu ku Bogu (ludzkiej natury). Toteż paraptoma i wynikająca $\mathrm{z}$ niej hamartia (grzech) rozumiane jako stopniowe oddalanie się od Boga-Stwórcy, dystansują byt stworzony od tego koronnego dążenia, co zatem wprowadza w nim wielopostaciowy stan choroby (chorobę duszy-psychiki-ciała „psychosomy”) (Pietkiewicz, 2018).

\footnotetext{
Orlof, W., Alifier, M. (2018). Nieeteryczny związek między duchowością chrześcijańską a zdrowiem człowieka. Elpis, (20), 119-128. https:// doi.org/10.15290/elpis.2018.20.12
} 
Antropologia chrześcijańska zakłada, że człowiek został stworzony przez Boga $\mathrm{z}$ dwóch elementów, mianowicie z ciała - czyli pierwiastka doczesnego, ziemskiego oraz pierwiastka eterycznego, nieśmiertelnego - czyli duszy. Dychotomia ciała i duszy koegzystuje z trychotomią (ciało - dusza - duch) $)^{6}$. W osiągnięciu pełni zdrowia psychosomatycznego niebywale ważne jest osiągnięcie harmonijnego współdziałania i współistnienia sfery duchowej ze sferą cielesną, ich harmonijnej i współbieżnej koegzystencji (Orlof i Alifier, 2018). Asceza, duchowa trzeźwość, modlitwa, oraz wszelkie praktyki religijne z sakramentem pokuty i Eucharystii na czele tworzą idealną terapię. Człowiek nawraca się ontologicznie, odwracając się od przeciwnego naturze patologicznego stanu i powraca do Boga, odzyskując zdrowie swej natury (Larchet, 2013, s. 10). Początkowo uzdrawia się to, co duchowe, czyli to, co związane z duszą, następnie psychika i somatyka.

Stan Raju, w którym człowiek żył w jedności z podstawową naturą, jawi się więc jako stan zdrowia․ Na początku czasów człowiek nie znał ni jednej choroby duszy i ciała. Prowadząc życie zgodne z jego naturą i z prawdziwym jej celem osiągamy stan zdrowia (Pietkiewicz, 2018).

\section{Święci pomostem między światem materii i ducha}

Kościół „pierwszych chrześcijan” nie przestrzegał żadnej oficjalnej procedury wymaganej do „uznania” świętości. Początkowo Kościół „wynosił na ołtarze” i uznawał za świętych tych, którzy cierpieli męczeństwo w imię Chrystusa. Święci tacy, dzięki łasce Bożej nie potrzebowali oficjalnego urzędu kościelnego uznania. Lud chrześcijański, czytając żywoty konkretnych świętych, doświadczał nieraz cudów za ich wstawiennictwem, przyjmował ich i czcił jako świętych. Święty Jan Chryzostom, prześladowany i wygnany przez cywilną ludność i władze kościelne, został uznany za świętego Kościoła przez uznanie jego zasług po pewnym czasie. Święty Bazyli Wielki został przyjęty niespełna natychmiast po śmierci jako świętego Kościoła za sprawą ludu. Ostatnio w celu uniknięcia nadużyć Patriarchat Ekumeniczny wydał specjalną

\footnotetext{
Podstawy trychotomii znajdujemy w Piśmie Świętym czytając słowa świętego Pawła: ,sam Bóg pokoju niech was całkowicie uświęca, aby nienaruszony duch wasz, dusza i ciało bez zarzutu przygotowaly się na przyjście Pana naszego Jezusa Chrystusa" (1Tes 5, 23). Szeroko o tym problemie pisał Orygenes, dla którego słowa apostoła były absolutnie wiążące. Dusza ożywia ciało, czyni je „duszą żyjącą”, a duch „uduchowia” całą istotę ludzką. Innymi słowy, pierwiastek nieśmiertelny, czyli dusza, „ożywia" i nadaje wartość oraz sens pierwiastkowi doczesnemu, jakim jest ciało. Duch, będąc kategorią religijną, jest zasadą, która kwalifikuje, podkreśla, na wszystkim kładzie piętno innego bytu. Wyraża się poprzez psychiczność, jak i materialność, ubarwiając je swym jestestwem. Co duchowe, czyli to co związane z duszą, nie powinno być rozpatrywane jako trzecia płaszczyzna (czy inaczej trzecie piętro) struktury bytu. To, co wynika z ducha, pierwiastka boskiego, jest zasadą, która się wyraża poprzez to, co psychiczne, i przez to, co cielesne, czyniąc oba te elementy duchowymi.

Pojęcie ,zdrowy” w języku cerkiewnosłowiańskim CS znaczy „cełyj”, tzn: cały, zintegrowany, zharmonizowany, zjednoczony.
}

encyklikę (tomos) (doprecyzować, uzupełnić), w którym określono, że Synod Święty „rozpoznaje” lub akceptuje świętość przedstawianych mu jednostek (Orthodox Saint of the Day. A daily reading of the 366 Saints from the Orthodox tradition, 2013).

Żywoty świętych są ważnym zasobem wiedzy dla każdego, kto zajmuje się historią późnego starożytnego świata, Bizancjum lub Średniowiecza. Gdy wszelkie gatunki starożytnej literatury zostały zakazane lub zapomniane, gatunek hagiografii stał się główną formą literacką. Żywoty świętych, inaczej vitae, przetrwały w zadziwiającej liczbie. Uważne ich odczytanie i studiowanie ujawnia nadzwyczaj wiele na temat życia zakonnego w okresach, które je zrodziły. Często jednak takie utwory hagiograficzne są jednymi z najlepszych źródeł podstawowej historii społecznej i kulturowej. Dostarczają informacji między innymi o szczegółach codziennego życia, organizacji lokalnego społeczeństwa wiejskiego i miejskiego, wpływu handlu, relacji płci, stosunków klasowych, często nawet wyczytać w nich można konkretne daty z historii wojskowości i polityki.

Bycie świętym to nie kwestia osiągnięcia czegoś lub dokonania. Świętym nie zostaje się za to „co zrobiliśmy, ale za to, kim jesteśmy w Chrystusie" (Watson, 2017a, s. 23).

Wielu teologów, (Delahaye, 1962; Hackel, 1981) klasyfikuje ogólnie świętych na siedem kategorii: 1. Apostołowie, czyli Ci, którzy jako pierwsi rozpowszechnili przesłanie Wcielonego Słowa Bożego i głosili zbawienie poprzez Chrystusa; 2. Prorocy, ponieważ przepowiadali i prorokowali przyjście Mesjasza; 3. Męczennicy, czczeni są za poświęcenie życia i nieustraszone wyznanie Jezusa Chrystusa jako Syna Bożego i Zbawiciela ludzkości; 4. Ojcowie i hierarchowie Kościoła, którzy osiągnęli sukces wyjaśniając i broniąc chrześcijańskiej czystości wiary i tradycji słowem i czynem; 5. Monastycy (Mnisi), którzy mieszkali na pustyni i poświęcili się ćwiczeniom duchowym (ascezom), osiągając, w miarę możliwości, doskonałość bliską Chrystusowi (przebóstwienie); 6. Sprawiedliwi, czyli ci, którzy żyli w świecie, prowadząc wzorowe życie jako duchowni lub świeccy wraz ze swoimi rodzinami, stając się przykładem naśladowanie w społeczeństwie; 7. Cudotwórcy, którzy byli w stanie dokonać cudów za życia lub po śmierci (Charkiewicz, 2014).

\section{Modlitwy do świętych}

Modlitwa w chrześcijaństwie zajmuje wyjątkowe i szczególne miejsce i znaczenie. Stanowi ona zarówno fundamentalną część wszystkich nabożeństw kościelnych, jak i indywidualnych peregrynacji. Modlitewna łączność oraz obcowanie ze świętymi w swej istocie jest urzeczywistnieniem w praktyce łączności Kościoła ziemskiego $\mathrm{z}$ transcendentnym Kościołem niebiańskim. Integracja, złączenie tych dwóch światów wyraża się w tym, że żyjący na ziemi modlą się za swych zmarlych przodków, zaś święci modlą się do Boga za żyjących obecnie, by wszyscy byli zbawieni. 
Praktyki religijne, w tym modlitwa, zostały wielokrotnie powiązywane $\mathrm{z}$ leczeniem wszelakich chorób na przestrzeni historii. Ludzie modlą się o dobre zdrowie lub proszą o uzdrowienie $\mathrm{z}$ choroby. Istnieje wiele przekonujących dowodów naukowych sugerujących, że modlitwa może przyśpieszać lub wręcz indukować uzdrowienia ${ }^{8}$. Stwierdzono m.in., że medytacja transcendentalna z dominacją mistyczną daje znaczące efekty prozdrowotne (Andrade i Radhakrishnan, 2009; Wachholtz i Pargament, 2005, 2008).

Wśród grona licznych świętych lekarze posiadają swoich patronów, zaś ich podopieczni - pacjenci, wielu orędowników w chorobach wszelakich. Mnóstwo pacjentów, jak i lekarzy codziennie zanosi prośby i zwraca się z prośbą o wsparcie podczas walki z chorobami. $\mathrm{Z}$ pomocą świętych orędowników i Jezusa Chrystusa czy Bogurodzicy, błagający zostaną w taki czy inny sposób uwolnieni i uzdrowieni (par. Flp 1, 18-19).

\section{Uzdrowienie za Bożym przyzwoleniem}

W Nowym Testamencie termin terapeuto pojawia się czterdzieści trzy razy (z czego czterdzieści w Ewangelii oraz w Dziejach Apostolskich) i dotyczy on problemu uzdrawiania. W sercu swojej ziemskiej posługi - Jezus Chrystus uzdrawiał, potwierdzając tym swoje posłannictwo, jak również prorocko wskazywał na „większe” uzdrowienie, którym jest duchowe odrodzenie i uświęcenie (Watson, 2017a, s. 350). Uzdrowienie ciała zatem polega na zmianie i odrodzeniu stanu fizycznego ciała tak, aby mogło ono funkcjonować prawidłowo. Uzdrawianie jest pragmatycznym zastosowaniem pierwszorzędnego poselstwa o zbawieniu, łasce i przekonaniem, że Jezus pragnie uwolnić człowieka od jego grzechów i od jego emocjonalnych i fizycznych chorób, „Przyjdźcie do Mnie wszyscy, którzy utrudzeni i obciażeni jesteście, a Ja was pokrzepię" (Mt 11, 28).

\section{Obcowanie świętych}

Od początku istnienia Chrześcijaństwa spotykani byli święci lekarze i uzdrowiciele - ludzie, leczący w imię Chrystusa i poprzez Niego (Jezusa). Ich medyczna specjalność i autorytet nie mieszały się z ich głęboką wiarą. Dla nich nie było podziału między nauką i religią, wiarą i doświadczeniem. Ich życie, służba Bogu, ludziom i nauce niech będzie przykładem dla współczesnych lekarzy naszych dni.

Istnieje stały związek między widzialnym i niewidzialnym kościołem. Dlatego każdego dnia roku świętujemy pamięć określonych i znanych z imienia świętych. Hymny

\footnotetext{
Zob. „Nieeteryczny zwiazek między duchowościa Chrześcijańska a zdrowiem czlowieka"

9 Często także tłumaczone: Ja was uzdrowię.
}

śpiewane na ich cześć mówią o ich zmaganiach, zasługach oraz prośbach, by orędowali za nami przed obliczem Stworzyciela. W Bożym Królestwie, jak zostało objawione św. Janowi, wznosi się ,,dym kadzidet z modlitwami świętych”.

\section{Święci od wszelkich chorób}

Na ścianach domów zwykłych ludzi, a także w szpitalach, przychodniach, sanatoriach oraz $\mathrm{w}$ gabinetach lekarskich spotykamy krzyż. Wciąż przy łóżkach mnóstwa pacjentów można spotkać obrazki (ikony) wielu świętych lub książeczki z modlitwami. Bardzo ciekawa jest historia wielu świętych portretowanych na owych obrazkach (ikonach). Życie wielu świętych i niejednokrotnie ich męczeństwo i śmierć mogą być przykładem życia i stawiania oporu problemom. Poniżej przedstawiono listę niespełna setki świętych orędowników w wielu chorobach. Wielu wymienionych świętych nazywanych było także świeckimi lekarzami, wielu uzdrawiało już za życia. Wszyscy są orędownikami przed obliczem Chrystusa i przedstawiają Bogu nasze prośby i błagania.

Agapit Peczerski (XI w.) leczył ciężko chorych, jest patronem lekarzy. Agrypina Męczennica (III w.) rzymianka - jej święte relikwie zostały przeniesione z Rzymu na Sycylię, gdzie wielu otrzymało cudownych uzdrowień. Aleksander Świrski (XVI w.) posiadał dar uzdrawiania. Z 23 opisanych cudów połowa dotyczy wyleczenia sparaliżowanych. Wierni modlą się do niego w intencji posiadania potomstwa. Aleksy, Metropolita Moskiewski (XIV w.), za życia leczył ból głowy. Alipij Peczerski (XII w.) za życia leczył trąd i inne choroby. Nawoływał do wyzbycia się z grzechu, który utożsamiał z przyczynkiem chorób. Anastazja z Dalmacji Wielkomęczennica (IV w.) - chrześcijanka, rzymianka, dziewica. Pomaga w trudach rodzenia, ciężkiej ciąży. Andrzej Apostol - wiele cudów dokonał w miasteczku Patras (Grecja): ślepi zobaczyli, chorzy doznali uzdrowienia. Orędownik w intencji posiadania potomstwa. Andrzej blogosławiony (X w.) jurodiwy - szaleniec Boży, miał dar uzdrawiania tych, którzy postradali zmysły. Antoni (IV w.) asceta żyjący na pustyni, leczył modląc się za chorych bez sił. Antoni, Eustachy i Jan Wileńscy męczennicy (XIV w.) - modlitwa do tych świętych uzdrawia z chorób nóg. Artemiusz sprawiedliwy, młodzieniec (IV w.) po modlitwach do niego wierni zdrowieją od bólu brzucha, a także przepukliny. Atanazja ihumenia (IX w.) - za życia nie chciała wyjść za mąż, pragnęła poświęcić się Bogu. Wolą rodziców było, by wyszła za mąż - dwa razy. Po drugim zamążpójściu udała się na pustynię. Żyła świętym życiem. Modlitwy do niej wznoszą osoby prosząc, by dobrze wyjść drugi raz za mąż. (by drugie małżeństwo było dobre)

Barbara Wielkomęczennica (IV w.) - uzdrowienia od ciężkich chorób. Bazyli błogosławiony, cudotwórca moskiewski (XVI w.) - pomaga przede wszystkim przy chorobach oczu. Bazyli Nowgorodzki (XIV w.) - pomaga przy chorobach wrzodowych. Bazyli Nowy (X w.) - pomaga w gorączce. Bazyli Sebastyjski Męczennik (IV w.) 
modlił się do Boga, by uleczyć ludzi z chorym gardłem. Do niego modlą się osoby przy chorobach gardła i w niebezpieczeństwie uduszenia. Bonifacy Męczennik (III w.) do niego modlą się osoby uzależnione od alkoholu. Borys i Gleb Książęta (XI w.) - modlitwa do owych świętych pomaga w bólach nóg. Charłampij męczennik (III w.) uważa się go za uzdrowiciela od wszystkich chorób. Święty zginął za wiarę chrześcijańską w 202 r. Miał 115 lat, kiedy uzdrawiał nie tylko powszechne choroby, ale i zarazę. Przed śmiercią Charłampij modlił się o to, by jego relikwie zapobiegały zarazie i uzdrawiały chorych. Chryzant i Daria Śww. (III w.) do nich pary modlą się o szczęśliwy związek małżeński oraz o zdrowie w rodzinie. Cyrus i Jan, męczennicy darmo leczący (IV w.) - patroni chorych na ospę oraz przy ogólnym stanie chorobowym. Damian, prezbiter i lekarz klasztoru Peczerskiego (XI w.) - leczył chorych modlitwą i św. olejem. Jego relikwie uzdrawiają chorych. Diomid męczennik (III w.) - pomaga w ciężkim stanie chorobowym. Dymitr Rostowski (XVIII w.) - pomaga przy boleściach klatki piersiowej. Dymitr Sołuński Wielkomęczennik (IV w.) - po jego modlitwach ślepi odzyskują wzrok. Ewdokia Pierwsza męczennica (II w.) - przyjęła chrzest i zrzekła się swego majątku. Otrzymała od Boga dar czynienia cudów. Do niej modlą się kobiety, które nie mogą zajść w ciążę. Ewdokia, księżna moskiewska (XV w.) - za jej wstawiennictwem ludzie modlą się o uzdrowienie z paraliżu i odzyskanie wzroku. Flor i Laur Męczennicy (II w.) - mieszkali w Ilitrii. Bóg obdarzył ich darem leczenia różnych chorób w tym alkoholizmu. Guryj z Kazania (XVI w.) - święty przywoływany podczas mocnych bólach głowy. Hipacy Rufianski - do niego modlą się osoby nie mogące mieć dzieci. Hipacy Peczerski (XIV w.) - za życia był lekarzem i pomagał przede wszystkim kobietom w sprawach miesiączkowych. Matki modlą się do niego o mleko w piersi, by móc karmić. Irynarch pustelnik z Rostowa (XVII w.) - święty, który pomaga w bezsenności. Jan Chrzciciel (I w.) - pomaga przy nieznośnym bólu głowy. Jan Rylski (XIII w.) - orędownik w problemach z mową i słuchem. Jan Teolog Ap.i Ew. (I w.) - opiekun osób chcących zachować czystość cielesną. Jan z Damaszku (VIII w.) - do Św. Jana wznosimy modlitwy o uzdrowienie od bólów rąk i kalectw. Jerzy Zwycięzca Wielkomęczennik (IV w.) - do świętego ludzie modlą się w chwilach zmartwienia i smutku. Joahim i Anna, rodzice Matki Bożej - pary modlą się do nich przy bezpłodności. Jonasz, metropolita Moskiewski (XVw.) - pomaga w bólach zębów. Katarzyna Wielka męczennica (IV w.) - do św. Katarzyny modlą się kobiety, by pomogła w ciężkim porodzie. Konon Męczennik (III w.) - jeszcze za życia leczył chorych na ospę i do niego właśnie o tę pomoc modlą się również ludzie współcześni. Kosma i Damian, darmo leczący i uzdrowiciele (III w.) - patroni lekarzy, pomagają przy wielu chorobach: oczu, ospie. Leczyli nie tylko ludzi, ale i zwierzęta. Orędownicy w chorobie. Ksenia $z$ Petersburga (XVIII-XIX w.) - uzdrawia chorych cierpiących. Longin Setnik Męczennik (I w.) za życia miał chorobę oczu. Był strażnikiem podczas ukrzyżowania Chrystusa. Kiedy krew z przebitego żebra Zbawiciela kapnęła mu w oczy - wyzdrowiał. Kiedy ścięto mu głowę, ślepa kobieta ujrzała - i to był pierwszy dokonany cud za jego wstawiennictwem. Do św. Longina ludzie modlą się, by odzyskać wzrok. Lawrencjusz Rzymski Męczennik (III w.) - za życia uzdrawiał ślepych, do niego modlą się ludzie mający chore oczy. Lukasz, Apostoł i Ewangelista (I w.) - lekarz, orędownik w różnych chorobach, ale przede wszystkim chorobach oczu. Patron okulistów. Lukasz, Biskup z Krymu Symferopolskij (XX w.) - patron chirurgów, lekarzy. Pomocnik w ciężkich przypadkach. Maron Syryjski (IV w.) - pomaga ludziom chorym w gorączce i chorobach, przy których ona występuję. Marufa, biskup Mezopotamski (V w.) - do niego modlą się ludzie cierpiący na bezsenność. Melania Rzymska (V w.) - za życia o mało nie umarła podczas ciężkiego porodu. Kobiety modlą się do niej o pomyślność podczas ciąży. Antypa Męczennik kapłan (I w.) prosi Boga, by z Jego łaski leczył ludzi od bólu zębów. Mikołaj (IV w.) - za życia leczył choroby oczu, przywracał ślepym wzrok. Minas Męczennik (IV w.) pomaga w biedzie, niemocy i przy chorobach oczu. Mojżesz Etiopczyk (IV w.) - Do niego ludzie modlą się podczas choroby alkoholowej. Mojżesz Ugryn - Peczerski (XI w.) - do świętego modlą się osoby, które proszą, by dodał im sił w walce $\mathrm{z}$ cielesnym grzechem. Nekatriusz z Eginy (XX w.) - pomaga tym, którzy proszą go o pomoc, w każdej chorobie, a przede wszystkim w chorobie onkologicznej. Nikita (XII w.) biskup Nowogrodu. Cudotwórca przede wszystkim pomaga ludziom w uzdrowieniu od ślepoty. Nikita Wielkomęczennik (IV w.) - do świętego modlą się osoby o uzdrowienie dzieci, przede wszystkim chorych na padaczkę. Nikita, biskup z Nowogrodu (XII w.) - za życia, uzdrowiciel ludzi ślepych. Modlą się do niego osoby niedowidzące, słabo widzące. Pantelejmon Wielkomęczennik, lekarz (IV w.) - za życia wskrzesił zmarłe dziecię, które zostało ukąszone przez jadowitą żmiję. Uzdrawiał od różnych chorób dorosłych, dzieci. Paraskewa Piatnyca Męczennica (III w.) - uważa się świętą za lekarkę różnych chorób, w szczególności chorób oczu. Także prosi się ją o pomoc w bólach głowy czy migrenie. Pimen Peczerski (Bardzo cierpiący) (XII w.) od dziecka cierpiał z powodu wielu chorób i dopiero przy końcu życia został uzdrowiony. Do świętego ludzie modlą się o uzdrowienie od długiego stanu chorobowego. Prokl Męczennik (II w.) - był lekarzem chorób oczu. Roman (V w.) - do niego modlą się osoby, które nie mogą mieć dzieci. Samson (VI w.) - modlitwami uleczał ludzi z różnymi dolegliwościami, chorobami. Serafim z Sarowa (XIX w.) - wielki molitwiennik, dniem i nocą modlił się do Boga. Po objawieniu się mu Matki Bożej zaczął leczyć tych, którzy do niego przychodzili, przede wszystkim pomagał ludziom z chorymi nogami. Sergiusz z Radoneża (XIV w.) - modltwa do Św. Śergiusza uzdrawia od „czterdziestu chorób” («сорока недугов»). Spirydon z Trymofuntu Cudotwórca, biskup (IV w.) - jeszcze za życia uzdrawiał chorych. Modlitwa do tego świętego pomaga w różnych chorobowych stanach. Symeon Werchoturski sprawiedliwy (XVIII w.) - leczy długie ślepoty, zjawiając się chorym we śnie, a także pomaga $\mathrm{w}$ chorobach nóg. Taisija 
(IV w.) do niej modlą się kobiety o uzdrowienie od obsesyjnej cielesnej żądzy. Tarazjusz, biskup Konstantynopola (IX w.) - był obrońcą sierot, odtrąconych, nieszczęśliwych i posiadał dar uzdrawiania chorych. Teodor Stratelates Św.wielkomęczennik (IV w.) - święty uzdrawia od sideł diabelskich. Teodor Studyta (IX w.) za życia cierpiał z powodu bólu brzucha. Za swoim wstawiennictwem leczy choroby żołądkowo-jelitowe. Tomaida Egipska Męczennica (V w.) - święta pomaga w zachowaniu czystości, dziewictwie. Tryfon Męczennik (III w.) - od chłopięcych lat posiadał dar uzdrawiania chorych, w szczególności od chrapania. Wit Męczennik (IV w.) święty, zmarł za czasów Dioklecjana. Do niego modlimy się za uzdrowienie od epilepsji, padaczki. Witalij (VI-VII w.) podczas życia zajmował się nawracaniem nierządnic. Do niego ludzie modlą się, by wyrwać się ze szponów żądz cielesnych. Włodzimierz Równy Apostołom książę (XI w.) - do świętego wierni modla się o pomoc przy chorobach oczu. Zachariasz i Elżbieta Sprawiedliwi - rodzice Św. Jana Chrzciciela (I w.) - pomagają podczas ciężkiego porodu. Zotyk, pomagający sierotom (IV w.) - do świętego wznosimy modlitwy o uratowanie chorych od trądu (Delahaye, 1962; Hackel, 1981; Hieromnich Makarios z Simonos Petra, 1998, 1999, 2001, 2003, 2005, 2008b, 2008a).

\section{Podsumowanie}

Mimo upływającego czasu, rozkwitu nauk ścisłych oraz humanistycznych (w tym medycyny i psychiatrii), nadal istnieje $\mathrm{w}$ człowieku potrzeba więzi z istotą wyższą, z Bogiem. Związek między modlitwą a procesem zdrowienia został wykazany w wielu badaniach naukowych.

Nie ma dla człowieka większego i trudniejszego zadania niż przezwyciężenie grzechu, zwycięstwo nad samym sobą. Ów grzech i odejście od Boga przenika wszelkie elementy naszego ludzkiego jestestwa. Brak łączności z Logosem może być jedną z przyczyn chorób psycho-somatycznych. Praktyki religijne tworzą niewidzialny pomost między empirycznym światem materii a transcendentnym światem duchowym, są niezbędne w przywróceniu jedności z absolutem, jedności koniecznej dla zachowania pełni zdrowia.

Ponad dwa tysiące lat historii Chrześcijaństwa człowiek poprzez modlitwę, orędownictwo świętych, oczekuje daru duchowego oraz łaski uzdrowienia, często dzięki cierpliwości i wytrwałości otrzymuje pomoc, której potrzebuje.

\section{Bibliografia}

Andrade, C., Radhakrishnan, R. (2009). Prayer and healing: A medical and scientific perspective on randomized controlled trials. Indian Journal of Psychiatry, 51(4), 247-253. https://doi.org/10.4103/0019-5545.58288.

Barclay, W. (1982). Daily Study Bible: The Letter to the Romans (wyd. 1). London: Westminster John Knox Press.

Biblia Jerozolimska (2006) (Wyd. 1). Poznań: Wydawnictwo Pallottinum.

Bułgakow, S. (2011). Światło wieczności. Medytacje i spekulacje. (W. Polanowski, red.) (Wyd. 1). Kęty: Wydawnictwo Marek Derewiecki.

Charkiewicz, J. (2014). Kult świętych w Prawosławiu. Elpis, 12, 109-159. [online] https://elpis.uwb.edu.pl/index.php/Elpis/ article/view/52, [24.08.2019].

Chuengsatiansup, K. (2003). Spirituality and health: An initial proposal to incorporate spiritual health in health impact assessment. Environmental Impact Assessment Review, 23(1), 3-15. https://doi.org/10.1016/S0195-9255(02)00037-9.

Delahaye, H. (1962). The Legends of the Saints. New York: Fordham University Press.

Hackel, S. (1981). The Byzantine Saint, University of Birmingham 14th Spring Symposium of Byzantine Studies. (Wyd. 1) London: Fellowship of St. Alban and St. Sergius.

Hieromonk Makarios z Simonos Petra. (1998). The Synaxarion: The Lives Of The Saints Of The Orthodox Church, Tom 1: Introduction, September, October. Ormylia, Chalkidike, Greece: Holy Convent of the Annunciation of Our Lady.

Hieromonk Makarios z Simonos Petra. (1999). The Synaxarion: The Lives Of The Saints Of The Orthodox Church, Tom 2:
November, December. Ormylia, Chalkidike, Greece: Holy Convent of the Annunciation of Our Lady.

Hieromonk Makarios z Simonos Petra. (2001). The Synaxarion: The Lives Of The Saints Of The Orthodox Church, Tom 3: January, February. Ormylia, Chalkidike, Greece: Holy Convent of the Annunciation of Our Lady.

Hieromonk Makarios z Simonos Petra. (2003). The Synaxarion: The Lives of the Saints of the Orthodox Church, Tom 4: March, April. Ormylia, Chalkidike, Greece: Holy Convent of the Annunciation of Our Lady.

Hieromonk Makarios z Simonos Petra. (2005). The Synaxarion: The Lives Of The Saints Of The Orthodox Church, Tom 5: May, June. Ormylia, Chalkidike, Greece: Holy Convent of the Annunciation of Our Lady.

Hieromonk Makarios z Simonos Petra. (2008a). The Synaxarion: The Lives Of The Saints Of The Orthodox Church, Tom 7: Appendix, General Index. Ormylia, Chalkidike, Greece: Holy Convent of the Annunciation of Our Lady.

Hieromonk Makarios z Simonos Petra. (2008b). The Synaxarion: The Lives ofthe Saints of the Orthodox Church, Tom 6: July, August. Ormylia, Chalkidike, Greece: Holy Convent of the Annunciation of Our Lady.

Hume, G. B. (1983). W poszukiwaniu Boga (Wyd. 2). Warszawa: PAX.

Larchet, J. C. (2013). Terapia chorób duchowych. Wstęp do tradycji ascetycznej Kościoła prawosławnego. Hajnówka: Wydawnictwo Bratczyk.

Orlof, W., Alifier, M. (2018). Nieeteryczny związek między duchowością chrześcijańską a zdrowiem człowieka. Elpis, 20, 119-128. https://doi.org/10.15290/elpis.2018.20.12. 
Orthodox Saint of the Day. A daily reading of the 366 Saints from the Orthodox tradition. (2013). [online] http://www.orderofsteugene.com/PDF/Saint_Day_book/DAILY_READINGS_OF_ORTHODOX_SAINTS.pdf, [24.08.2019].

Pietkiewicz, P. (2018). Zdrowie człowieka i przyczyny jego utraty według antropologii prawosławnej. Elpis, 20, 253-257. https://doi.org/10.15290/elpis.2018.20.26.

Śliwerski, B. (2007). Samowychowanie jako odrodzenie moralne. Przegląd Pedagogiczny, (1), 15-34. [online] http://cejsh. icm.edu.pl/cejsh/element/bwmeta1.element.desklight-7edf09fb-7c88-4bd0-8529-bf0d9c6d6551, [24.08.2019].

Wachholtz, A. B., Pargament, K. I. (2005). Is spirituality a critical ingredient of meditation? Comparing the effects of spiritual meditation, secular meditation, and relaxation on spiritual, psychological, cardiac, and pain outcomes. Journal of Behavioral Medicine, 28(4), 369-384. https://doi.org/10.1007/ s10865-005-9008-5.

Wachholtz, A. B., Pargament, K. I. (2008). Migraines and meditation: does spirituality matter? Journal of Behavioral Medicine, 31(4), 351-366. https://doi.org/10.1007/s10865008-9159-2.

Watson, J. D. (2017a). Słowo greckie na każdy dzień roku (Wyd. 1). Warszawa: Oficyna Wydawnicza VOCATIO.

Watson, J. D. (2017b). Stowo hebrajskie na każdy dzień roku (Wyd. 1). Warszawa: Oficyna Wydawnicza VOCATIO.

Rozmiar artykułu: 0,9 arkusza wydawniczego 